\title{
Religion and Family
}

\author{
Behzad Ghobadi \\ Master's degree in consulting
}

\begin{tabular}{|c|c|}
\hline ARTICLE INFO & ABSTRACT \\
\hline $\begin{array}{l}\text { Keywords: } \\
\text { Religion } \\
\text { Family }\end{array}$ & $\begin{array}{l}\text { The family institution and the factors influencing its education and } \\
\text { strengthening are among the issues that have been considered } \\
\text { seriously in religious teachings. There is a lot of moral and religious } \\
\text { prayers in religious texts that the commitment to them strengthens } \\
\text { and strengthens the family. The author of this article has tried to study } \\
\text { and analyze the teachings and the purpose of this study is to achieve } \\
\text { these teachings. Thus, at the beginning, a glance at the place of } \\
\text { worship and belief in the family, and then, while listing the views of } \\
\text { beliefs and practices, we explain the role of each of them. The writer's } \\
\text { method in his review was documentary, and by referring to the main } \\
\text { texts of the teachings of Islam, he explained the problem. }\end{array}$ \\
\hline
\end{tabular}

\section{Introduction}

Concerning the factors influencing the strength, strengthening the family, this question arises that the commitment to religious beliefs and devotional teachings play a role in strengthening the foundations of the family, especially in their moral and spiritual education. It is clear to every Muslim and believer that worship and spiritual connection with the Almighty Creator is a boom from the depths of human existence that illuminates the radius of its light, life, and community, and gives life a meaningful and conceptual correctness. The origin of the worship of nature is pure and uncontrollable, and the intrinsic and intrinsic essence of mankind, which, if properly guided, connects man to his high goals, which is prosperity. For this reason, the promotion of worship and the dissemination of the valuable tradition of prayer to the Holy Trinity has been the subject of the teachings of all prophets.

The teachings and teachings of Islam in the field of worship and prayer are divided into two parts, which, of course, are closely related. The first part of this doctrine is believing in and believing in God, the prophets, the infallible Imams and the Hereafter. The practical commitment to the religious, spiritual, and worshipful practices that come through the revelation or through the Almighty God has included another part of the teachings and teachings of Islam. In this paper, we are going to study the role and place of devotional and spiritual teachings in relation to family and children, and by analyzing and interpreting the teachings of their role in the education, strengthening and strengthening of the family. Our methodology will be analytical and documentary.

\section{The role of beliefs in family consolidation}

Having wives has a significant impact on religious beliefs and beliefs in family consolidation. Alienation and disregard for religious beliefs and beliefs will cause serious problems in life. The Holy Quran says: "Anyone who turns away from my memory will be in a difficult life." (Taha: 124) It is clear that the commemoration and commemoration of God, from the beliefs and beliefs, are the Creator and the belief in monotheism. Being in a difficult life can be due to the greed, fear and anxiety resulting from this decline. 
A rejection of religious beliefs brings calm and pleasure out of life, causing surprise and wandering and feeling absurd. Maybe in spite of the good material facilities and welfare it has, but there is no peaceful and safe life.

Regarding the influence of religious beliefs on mental relaxation, in addition to religious teachings, several psychological researches have been done that will be discussed in the discussion; in this section, we will mention only a few of them.

Religious beliefs and beliefs have different manifestations, which are, of course, along each other. These manifestations are:

\section{Belief in God}

Religion and religious beliefs provide a comprehensive interpretation of human life by providing a comprehensive framework for the interpretation of events, as well as providing concrete and convincing answers to questions of existence, such as where I came from and where I go, by creating a sense of meaning for the moment. It solves it. The healthiest aspect of religion is its ability to reduce fears and anxieties by giving it a thought that has a sense of control over this material world and can overcome the problems, under the power of God. The power of the highest powers and the will of the will. This belief is the same belief in the only God that is considered the most important religious belief.

Monotheism and theology lead to a person's attitude towards all being and human life, purposeful and meaningful, and act in solidarity, unity and calmness in behaviors. Believing in God leads all behavior and family life to the satisfaction of God. A person who observes God and comes closer to himself and even to his neck, strives to satisfy his family in dealing with family members and family responsibilities. Attention to God's justice and the fact that he does not endure any form of oppression and does not harm the right of any creature is another cognitive framework for controlling the behavior of family members. Whatever the situation is, the person's problems will be less, and such individuals will not require the external supervisor and arbitrator to solve their problems. Paying attention to the attributes of God, including widespread mercy and kindness, unlimited ability, support for their creatures, including human beings and their adequacy, also have a positive effect on one's life and its family aspects. The affection and mercy of the members of the family toward each other, which are the branches of the manifestation of God's mercy, is the ground for the prevention and resolution of many problems. Trust in God, that is, the trust and reliance on his power in all matters of life, is from the effects of faith in God. Sometimes the weakness of will, fear, sadness, anxiety, and lack of complete understanding of the situations make it impossible for an individual to take appropriate measures to solve the problem of exploitation. Trust in God strengthens the will and lessen sides the psychological factors and makes the person more capable of solving the problems of life and attaining balance and harmony. Families throughout life are confronted with many problems that some economies, such as low income, bankruptcy or robbery of property and unemployment, some relate to the health of the members, such as sickness, disability and death, and some return to relationships and problems. Under such conditions, trust in God helps to strengthen the will of family members and more. In addition, in dead ends and conditions that appear to show all the material signs and symptoms of nonsolving the problem, trusting God opens the door to people and sometimes solves problems from ways people do not think. Empirical research on the relationship between self-esteem and self-esteem confirms this point. In a study by Mohammad Sadegh Shojaee about his relationship to self-esteem, this conclusion is reached that those who believe in God have a high self-esteem and a feeling of strength and effectiveness in life. They are resistant to life problems and overcome the problems with the strong wills that they have gained in the trust of God. 
If we take a look at the life of the parents of God and the prophets as well as the successful ones, we will realize that on the shadow of faith in God and His reverence. Prophet Shu'yyeb (AS) states the reason for his success and success against the problems and threats of the idolaters: My success is only from God. I believe in him and return to him (Hud: 88). An important point in the family is the mutual recognition of individuals to trust, which is more important for women and more positively evaluated, since the main responsibility for solving more problems is especially economic It is a man and his spiritual strength is important to others.

From the works of faith to God, submission and judgment are divine destinies. The emergence of this state is based on providing cognitive and emotional backgrounds. One must believe that all events in the world is subject to the permission of God and the power that he causes imparted it. (Kahf: 39: Isra ': 20) In addition, God not only about the interests of people aware, but Khyrkhvahtr and Sadttlbtr of They themselves are themselves; therefore, all incidents occur in the direction of the goodness of human beings. The state of satisfaction with divine satisfaction makes family members a problem in life, positive and evolutionary, and the ground for compatibility with such incidents provides irreversibility and makes it easier to resolve disputes caused by these events. In this regard, several studies have confirmed the effect of religious beliefs on marital satisfaction. Other studies have identified religion as the main factor in the stability and stability of marriage.

\section{Belief in mission and imamate}

The second belief in religion, which is the pillar of religiosity, is believing in the mission of humans from God, who are known as divine prophets in history. The commandment and succession of the Prophets, known as "Imamate" in the Shi'i religion, are also in line with the fulfillment of the mission of the Holy Prophet.

In the life of man, the role of belief in the principle of prophet hood and Imamate returns to two dimensions: the first dimension is the teaching of religious affairs, especially life based on religious principles. The unique way of knowing the teachings of religion, after the word of God, is the words of the Prophet and his successors, so that even the correct use of the Word of God is based on the knowledge and understanding of the words of the parents of religion (AS). The second dimension in relation to belief in mission and imamate is their role. The principle of simulation, which, in the process of imitation and modeling of childhood in humans, is a key factor in learning, so that for children, imitation of good patterns, when dealing with problems or encountering the surrounding environment, has a very positive effect. Moreover, observing the model is one of the most effective and most effective methods among different learning methods. It is necessary to follow and replicate with the people whose teachings of religion are fully manifested in terms of family relationships and types of behaviors. Since individuals to learn the way of manners and appropriate behavior in the family, the samples moral objective in all aspects of life needs are, inevitably to such patterns are drawn, thus providing suitable samples, for better performance of individuals and families dealing with Life issues will be beneficial. In this regard, the Quran invites those seeking spiritual perfection to consider the Prophet (PBUH) as a good model of life. Also, in this regard, the behavior of the parents of religion (AS) is from the first to the last stage of family life in the classroom, such as: the selection of the wife, the dowry and the dowry, the marriage ceremony, the customs of all aspects, the way of dealing with the children; Trustworthy and complete.

\section{Belief in life after death}

The third important religious belief that can play a significant role in human life is believing in post-death life, auditing on the Day of Resurrection, and the reward and punishment of individuals based on their behavior. Although belief in resurrection affects all dimensions of 
human life, here emphasis is placed on family aspects. Today, despite the advances in science and the reduction of life problems, anxieties and worries are increasing. Part of these problems is due to the inevitable and inferiority of life. The belief in having a life after death also makes this problem worse. This has also had an adverse effect on the family. In a family that does not endorse beliefs, due to the neglect of transcendental goals, family functions are restricted to limited functions, and families are easily dissociated and dissolved due to inevitable. Believing in a life after death, the family is focused on the goals of sustainability that causes the transplantation of most family members; hence, in families with this belief, despite severe problems, such as handicaps, people who have long been mutually supportive and emotionally satisfying of life.

The second effect is believing in resurrection, creating motivation in people and encouraging them. In the words of the parents of religion (PBUH) there are references to the rewards and blessings of the future which are given to the person in return for performing family duties. Paying attention to these blessings and comfort in the afterlife prompts individuals to lead their behaviors in order to attain these blessings; for example, verses such as the following verses reinforce the enthusiasm of individuals in performing their duties: "You and your spouses in Have a great joy in Paradise. There are trays of gold and jewels in front of them, in which there is what the heart's desire and the eyes enjoy, and there you are eternal, and this is the heaven that you inherited for the acts that you were doing. "(Good: 70 72)

The third effect of belief in resurrection, which is not related to the second effect, is its role in the proper response to the problems. A family that is suffering from a lack of dear ones or a wide disability or severe economic problems is less likely to relieve him of something like belief in resurrection. Basically, some of the problems are irreparable, and people can only relax with respect to the rewards of the worldly life.

The fourth effect of belief in resurrection is its inhibitory and deterrent. Many of the family's problems relieve the inhibition of behaviors that plunge individuals into violating one another's rights, imposing on others and aggression. Believing in resurrection and recalling bad consequences, violating the rights of others and failing to carry out responsibilities, resists individuals to some extent from inappropriate behaviors. For example, one of the disadvantages of a family in the family is the spiritual pressure, in such a way that even if a person lives up to his duties in other dimensions, but he behaves inappropriately in the family, he is in extreme stress in the underworld. Also, in the words of the parents of religion (AS), the consequences of mistreatment with the wife are mentioned that the individual's attention to these unpleasant consequences in the afterlife can halt him to some extent from inappropriate behavior.

\section{The role of worship in consolidating the family}

In addition to the influence of religious beliefs and religious beliefs on the consolidation of the family, acts of worship which have a practical and practical side also have an enormous influence on the consolidation of the family. In this section, we will discuss examples of worship and their work, and finally, we will mention examples of empirical and field research.

\section{Prayer and family}

The Holy Quran says: "O you who believe, help you receive patience and prayer." (Al-Baqarah: 145) The worshiper, besides accepting the prayers of power and vitality, limits the ground of anxiety and disturbance among the members of the family through prayer and recitation God, spirituality and enlightenment penetrate the hearts of the members of the family, especially the husband and wife, in peace and security. Ali (AS) in this regard says: God's remembrance brings forth the brightness of the breasts and calmness of the hearts. Praying also blocks the scene of a family crisis by controlling the ugliness and unwillingness of the family. Because fugur and non-affection weaken the foundation of the family and crumble its strength. The holy Quran considers one of the characteristics of the prayers as a sanctity and maintains integrity; 
where it says: prayers are those who protect their own lips and protect from negation. (Excerpt: 29)

The empirical research carried out in this regard indicates that prayer and communication with God directly affects marital satisfaction and the strength of the family, or through the creation of attributes and attributes in those individuals that these characteristics contribute to the stability of life. Here are some examples of the research.

Sprawski and Hageston in an experimental and field study found that people who had lived together for a long time considered religion and religious behavior as the most important part of marital satisfaction. Jerigan and Neck, after examining their research, have concluded that religious behavior is the most important factor in the stability and stability of marriage. A group of researchers investigated the relationship between marital satisfaction and family solidarity with the husband and wife religion, and concluded that religiousness plays an important and effective role in the strength of the family.

Also, research shows that those who are committed to religious activities tend to have a more sustainable marriage than others. Most of these people have problems with communication, disagreement, lack of integrity and less substance use.

Coing and Larson also concluded from their research that there is enough evidence to prove that religious and religious behaviors are related to normal and healthy behavior. He says research has proven that religious people are less likely to suffer from sexual immorality, spouse abuse and alcohol.

In a research conducted by Nasyblbak and Bani-Sadi, which compared the personal, social and personality factors of individuals in Kermani's consistent and incompatible couples, they concluded that factors such as financial affairs, sexual relations, and religious beliefs affect the disruption of life, and beliefs Religious roles play a great role in strengthening the family.

\section{Fasting and Family}

Fasting is one of the greatest worship which has been emphasized in the Holy Qur'an and the traditions of the Ahlul-Bayt (AS).

One of the great benefits of fasting is the cultivation of the soul and the strengthening of will and adjustment of human instincts. Fasting, in spite of hunger, thirst and refusal of other pleasures to be neglected, strengthens the spirit and will of itself. Through the fast of power, self-restraint and lust are restrained. Also, the real day destroys the sins of the eye, ears, hands and feet. Because fasting knows that you should not open your eyes to haram and you should not hear haram. Imam Sadeq (AS) says:

Know that fasting is not just avoiding eating and drinking ... So when you are fasting, keep your tongue out of lies, cover your eyes with haram, do not fight with one another, do not envy one another, do not neglect one another. Do not argue, do not lie, do not disagree with each other, do not angry, do not abuse one another, do not harass each other, do not oppress others, do not hurt one another, and neglect God and forgetful prayer Do not go

In the divine and Islamic teachings, attention is also paid to the difference in people in religiosity, and it is emphasized that religiosity is some of the apparent person and is merely the language of the tongue. Even some people consider religion and religious values as a means to achieve worldly and worldly manifestations. Imam Ali (AS), while dividing the worshipers, says: A group worship God with the greed and gladness of paradise; their worship is the worship of the trafficked people; a group worship God from the fear of hell and its torment; this is the worship of the slaves, and a group of Allah They are glad to pray; this is the worship of the free and this is the best worship. Also, Imam Hussein (AS) said in a narrative:

It is true that a large number of the world's most despicable people are in the world and their religious values are their tongues. As long as they have faith in their livelihoods and their worldly life, and if the world becomes overwhelmed and tried, the faithful will be very low. 
Although all of these groups are seemingly Muslim, and have a wealth of religiosity, and in Islam none of these worshipers and believers have been rejected, but the value and the fruits of these will vary with each other. Then there will be pure and true worship to obey and obey God for his worth for worship. At this rate, the worshipers have reached a certain number, and it is one of the most prominent examples of this type of worshipers of Ali (AS) that he said: "God, I do not worship you, not in fear of hell and not in greed in paradise, but you are worthy of worship, obedience and worship I found you worshiping you. The more people can move to this royal (worship of Ali (AS)), their beliefs and worship will be deeper and more fruitful.

\section{Educational works of worship}

Each of the effects of worship has special spiritual and spiritual effects on spouses and children. The educational effects of worship on wives and the quality of its impact on the type of worship on the children is different; therefore, each of them is independently dealt with.

A. Educational effects of worship on wives

Exposures and evidences of worship in wives are many that refer only to examples.

\section{The Promoter}

Prophecy is one of the spiritual and moral diseases that has harmful effects on the community, especially the family. Many of the differences in the family are due to the spontaneity and selfcontrol of the spouses or one of them. One who quenches in his prayers for five days and ends in his prayers, and in every prayer goes to Rukh and Projour for several times, declares slavery and humility, he does not only protest against God but also to his servants, and the spirit of self-control and the bounty on her decreases. In prayers and prayers with the Holy Prophet and in Hajj and fasting, when the soul of submission to the command of the Lord is created in him, and confesses to the greatness of God in tawaf and prayer, he considers himself less than himself to consider himself superior to others and He wants to disobey. Prophet Ali (AS) is obliged on the works of worship, especially the works of prayer, to reduce and eliminate the promise of spirituality: God has obligated faith to eliminate the impurity of polytheism and prayer to purify the prophetic filth. And in another tradition which has come from the Prophet Muhammad (PBUH): The fast of the air breathes the soul and the lust of the animal nature (and floods it), in which the heart and purity of the members, and the outer and inner human being, And thanks for the blessings and the goodness of the poor and the excesses of supplication and crying; it is also a means of appealing to the Lord and breaking the attachments and the reduction of sins and the increase in the benefits and the numerous benefits.

Imam Khomeini (peace be upon him) says: "As the prayer of the ascension is complete and believers are close to those who believe in God, they find two consistencies, one of which is another introduction: first, the abandonment of selfishness and selfishness, that is, the truth and the inner self, and secondly, God-given and truth-seeking, which is the truth of ascension and glory. When in a family, the prowess, which is one of the moral issues, is restrained, a suitable place for the growth of ethical and spiritual virtues.

\section{The neglector}

Neglect has a widespread concept: being aware of the conditions of time and place of life, of the present and future and past realities, of its attributes and actions, of the messages and verses of the right, as well as of the warnings that the bitter and sweet events of life give to humans. Our point in this discussion is neglect of the remembrance of God and the manifestations of mankind.

The danger that "neglect", from the remembrance of God, realizes the perfection and progress of man, is more than what we often imagine. The neglect of our prosperity destroys us and burns up the life of the fire like a fire and all the abilities and talents of the goddess. When Prophet Muhammad (peace be upon him) went to the forehead, he received a number of 
statements from God, including: Ah! Do not neglect the one who thinks about me; I do not mind how he is destroyed in what way.

This statement clearly shows that the end of neglect of God is destruction and annihilation. Because it is the source of many sins, and it even makes humans more humble than animals. (Araf: 179)

Acts of worship, especially prayer, prayer and pilgrimage, make man to God and spiritual values, and remove man from neglect and place in the path of understanding and precision in the purposes of creation.

Mirza Javad Maleki Tabrizi says: The adhan is an invitation to visit the Holy Trinity as an act of worship. As they are summoned to the Lord on the Day of Judgment, in this world, with the adhan of the believers, they will be called to the Majles and the Ascension and pilgrimage of the Lord. The sense of being present in the rightful place brings man out of neglect, and points out that he must be alert and perform the duties of slavery well. When members of the family, especially the parents, are alert and neglected, they will also be subject to educational and moral duties, and their commitment will be effective in the children and lead them to spiritual and educational issues and through observational learning It will affect them.

\section{Relax your inner heart}

Belief in God, and the need and the need for him gives hope to mankind, and man feels he is relying on a safe and secure refuge; hence he has a sense of vitality and empowerment. Dale Carnegie writes: "When heavy work destroys our forces, and grief deprives us of all kinds of wills, and most of the time when the doors of hope are closed to us, we turn to God, but for whatever reason let the spirit of despair and Despair over us? Why do not we renew our forces by prayer and prayers, instead of praise and supplication of God.

Imam Sajjad (as) says in the prayer of Khums: "Our Lord! My joy and tranquility lies in your chains, and the illness and healing of my heart is burning, and the extinction of the heat of the heart and the repentance of your grief is with you.

\section{Educational works of worship on children}

In the formation of personality, behavioral, cognitive, emotional, religious, spiritual, and ... factors, several factors are effective and create them. One of the most important and important factors in this field is environmental factors. Environmental factors include family, school, peers, geographic environment, social environment, and so on. In this discussion, our focus is on the family environment and, in particular, on the influence of parents on children. Parents, especially parents, have the most influence on the various educational dimensions of children due to their first mentor and their continuous relationship with their children. For this reason, religious education has focused on the educational role of parents. In psychological discussions, most psychologists have also focused on the influence of parents on the formation of the character and behavioral characteristics of children.

Jung believes that in the childhood, what may be called the child's personality is nothing but the reflection of the personality of his parents. They can have a great influence on the development of child and child characteristics. Erickson, another psychologist, emphasizes the paramount role of children in their children and considers it a decisive factor.

In terms of how parents influence the spiritual issues of children, one can refer to methods and principles.

\section{Principles and methods of parenting}

Parents' commitment to worship and spiritual issues and the bringing of children in these fields, based on several bases and principles, are effective in their offspring and will have special educational and spiritual blessings upon them. These principles are: 


\section{The effect of appearance in the backend}

The meaning of appearance is everything that is visible and objectively concrete to man; and the meaning of the inner being is something that is not visible and is internal, such as thought, intention, will, cognition. Every act and work that appears to endanger humans, though artificial and unrealistic, affects the inside and the interior of man. Therefore, Islamic teachings have been ordered to bring human beings into special situations, in order to influence the work of the inner work. For example, a cry for Sayyid al-Shohada (AS) has been ordered to cry in the mourning party, and if not, take a cry (narration) and say in the narration of Imam Ali (AS): If you are not tolerant, then show yourself patience. How little does it take to make someone look like a group and not be a part of them?

Prophet Muhammad (AS) recommends to his son that when walking, he is mourning with pride on the earth; (Ex. 37) The mode of excitement and pride is a role and appearance of the pharaonicization of the heart. So here, too, the appearance has affected the backend.

When parents have spiritual devotions and spiritual issues, they create a spiritual home with their spiritual acts, and when they put their children in this spiritual and spiritual setting, they also have a spiritual and educational effect on their children, and they bring him to God and religion. Will draw.

\section{The gradual emergence of discipline and personality}

The personality and behavioral characteristics of human beings are gradually formed and gradually formed, and, as discussed at the beginning of the discussion, many factors are influential. One of the main factors is the family environment, especially parents. Parents can provide the necessary means for the spiritual growth and education of their children through the modification of the conditions and the spirituality of their creation and give their children a religious personality.

When the child spends most of his time in an atmosphere of emotional, friendly, kind and full of love of the Lord, all the necessary premises for the formation of a religious and spiritual personality are provided and the child's existence will be based on religiosity.

\section{Continuity and protection on action}

Because we are striving to shape the child's personality and behavior in a sustainable manner, we must follow the rules in the process of training them, which would result in the desired result. One of the most important and consequential rules in spiritual education is the principle of sustainability and protection. Continuity, quantity and protection is a function of the quality of action; the continuity of action demonstrates its continuity, and protects the practice, care and observance of its terms and conditions (conditions and conditions of action, whether it is internal or external) Consistency and protection is essential, because uncontrolled continuity is a formidable, habitual, dry and unconventional habit, and shelter less protection is not at all constructive.

In the Holy Quran, one of the characteristics of those who are safe from oscillations and deviations is to maintain your prayer and protect it. ... (men do), except those who pray that you keep your prayer ... and those who guard their prayers. (Excerpt, verses 23-34). If protection is not in prayer, it will not only not make salvation, it will cause uselessness and loses.

Continuity and repetition, as well as respect for the conditions of learning and the impact of the serious and substantive discussions in strengthening the mind, better learning and creation of cognition. In psychology, one of the most important causes of forgetfulness of information from memory is the neglect of it and also one of the ways to prevent forgetfulness, repetition and serious attention to that subject. Also, factors such as distraction, sleepiness, fading and discouragement are factors that reduce the focus of attention. 
According to the above mentioned points, firstly, parents should observe the continuity and repetition of their worship and not neglect the worship in any circumstances, and also introduce the children in their spiritual and spiritual communities, especially in prayer and pilgrimage, and bring them to this Work to get used to. For example, parents should pray, pray, spirituality in any situation such as weddings, travel, guests, sickness, etc., to consider the children of worship seriously and never imagine that worship for the time of unemployment and it's cool.

\section{When the sons of altzam and ss}

When the children observed the commitment and continuity of the parents to spiritual matters, especially prayer, prayer, and recitation of the Qur'an, they will play a role in their minds and a heart and soul desire will be created. Particularly if the parents have trained spiritual issues with respect to their children's spirituality and age.

4. Background and position preparation

Situations and behavioral characteristics of humans occur in the context of the situation and affect them. Hence, different situations are the basis and basis for shaping the behaviors and states of humans. Providing appropriate backgrounds and desirable situations is a facilitating factor for the emergence of desirable behaviors and practices.

In discussing spiritual education of children and in discussing spiritual parenting influence on children, attention to this principle is vital. Parents engage in children's behavioral development through their devotion to spiritual worship and, subsequently, the adoption and acceptance of their descendants in their spiritual and spiritual communities. When the father tries to prepare the conditions for prayer and recitation of the Qur'an by preparing a beautiful shawl for the children or a suitable place for prayer and prayer, he is in fact preparing the ground for the child's participation. Even some parents stepped up and regularly encouraged the children to materially and verbally, but they directly and indirectly talked about individuals and children who are interested in spirituality and worship.

It is clear that in these situations and conditions there is a sufficient incentive for the children to become parents as well, especially in such a situation that children can participate in worship without any problem. For example, in families with young boys and girls, and maybe they may be asleep in sleep or awakening, and they need ghusl tuberculosis, parents should even provide conditions that children can feel free to embarrass themselves. They are taught and ready to perform religious duties.

The point at the end of this discussion is that although repetition and continuity in influencing and role play is important, as we repeat many prayers, and repeat some of them, such as prayers, on the daily basis, even in psychology Propaganda, repetition, and continuity of propaganda principles have been proven to be proven to be high, but if there is no recurrence of attractiveness and diversity and innovation, it may have a negative effect, and this should be seriously correlated with the upbringing of children Pay attention.

For example, if parents take the children regularly to visit the shrine of the infallible Imams or regularly invite the prayer and recitation of the Qur'an, without considering the consideration of the children's abilities and desires, and without creating diversity and attractiveness in their work, Children may hate and do not show the willingness to do so. So, you should have the moderation and accuracy required. Imam Ali (AS) says: "No one likes anything and is not attractive to him, and he is an enemy, he does not like to look at it and be reminded of him." It is used extensively from this command that we must do something for the children to do the devotional service with enthusiasm and enthusiasm, and it will have a negative effect.

\section{Conclusion}

The role of religious beliefs in educating family members is crucial. The effect of the devotional teachings on strengthening and strengthening the family is serious and awesome. 
The worship and beliefs of individuals are properly and clearly expressed in religious texts. Spouses have a great role in the tendency of children to worship and spirituality through the pattern of being and for children.

In a family of practical commitment to beliefs and devotions, mental relaxation, internal lightning, and ethical issues spread. Hope, material and spiritual progress, as well as sense of conscientiousness towards others in the faithful and worshiping families are very high.

\section{References}

Ahmadi Abhari, Ali, Thought and Behavior, The Paper of the Role of Belief and Religious Belief in the Treatment of Diseases, Annexes 9 and 10, Tehran, Institute of Psychiatry, 1997, p. 4057.

Buria, Nasser et al., Growth Psychology with Attitudes Toward Islamic Resources, Tehran, 1975.

Carl, Alexis, Prayer, Ali Shariati translation, Tehran, Elham, 1998.

Devan Schultz, Theories of Personality, Translation by Yahya Seyyed Mohammadi, Tehran, ed., 2005.

Dilami, Hassanbn Mohammad, Ershad al-Qalub, Qom, Shariffazdi, 1412 AD.

Experienced, Peyman and Associates, "The Role of Religion in Life", Psychology, Vol. 41, 1386, 25, 40.

Fontana, David, Psychology of Religion and Spirituality, Translated by Sawar, Tehran, Religions, 2006.

Ghobari Bonab, Baqir, "Religious Beliefs and Their Effects on Mental Health", Thought and Behavior, p. 4, 1374, p. 4058.

Hagh Faghi, Mohammad bin Hassan, Al-Shi'a, Al-Shi'a, Qom, Alibalit Institute, 1412 AD.

Heidari, Mojtaba, Religiousness and Family Satisfaction, Qom, Imam Khomeini College, Institute of Education and Research, 2006.

Hosseini Dashti, Mostafa, Ma'aref and Maarif, Qom, Bina, 1997

Imam Khomeini (RA), Adab al-Sulveh, Tehran, Institute for the regulation and publication of works by Imam Khomeini (RA), 1370.

Khansari, Jamal al-Din Muhammad, Describing Gharrul-Hakam and Dar al-Kalam, (Takimidiyyyyy), Tehran, Tehran University, 1373.

Nahj al-Balagha, Translated by Seyed Ja'far Shahidi, Tehran, Islamic Revolution and Education, 1993

Panahi, Ali Ahmad, Relaxation in the Light of Prayer, Qom Imam Khomeini Institute of Education and Research, 2005

Salarifar, Mohammad Reza, Family in the Attitude of Islam and Psychology, Qom, Institute of Hawaii and University, 2007.

Shamloo, Saeed, Schools and Theories in Personality Psychology, Tehran, Growth, 1995.

Shojaeean, Reza, "The Relationship of Prayer to Mental Health," Thought and Behavior, p. 3, 1381. p. 58. 70.

Shojaei, Mohammad Sadegh, Belief in God, Qom, Imam Khomeini College, Institute of Education and Research, 2004.

Tabatabaei, Seyyed Mohammad Hossein, Shiite in Islam, Qom, Islamic Publications Office, 1373.

Tabrasi, Fazlben Hassan, Makaram al-Kahlagh, Tehran, Dar al-Katl al-Islam, 1376 AH. 